\title{
SYNOPSIS
}

News

$\bullet$

AnALYSIS

- Practice

\section{Drug Safety}

\section{FDA urges "black box" warning on pediatric antidepressants}

A blue-ribbon scientific advisory panel has urged the US Food and Drug Administration (FDA) to include "black box" warnings on selective serotonin reuptake inhibitors (SSRIs) advising of the increased risk of suicidal behaviour among pediatric users. Black box warnings are typically reserved for lethal drugs.

The panel's vote on Sept. 14 followed 2 days of often-emotional testimony from parents who were unaware of the risks of SSRIs before the suicides of their children.

The FDA, which isn't obliged to adopt the recommendations of its scientific advisory panels, but has typically done so, states that it is changing labels to "enhance the warning" and "bolster the information provided to patients."

The panel had also urged the FDA to insist that parents sign consent forms indicating that they understand the risks before their child begins taking SSRIs, and that brochures be distributed to parents outlining the pros and cons of their use.

It did not, however, conduct a vote on whether to follow the lead of Great Britain and impose an outright ban on pediatric use of SSRIs other than fluoxetine (Prozac).

In June 2004, Health Canada issued a general warning about SSRIs, although it had not found a "direct link between taking SSRIs and incidents of death." The FDA issued an advisory in March.

FDA figures indicate that over 10 million, or roughly $7 \%$ of antidepressant prescriptions, are now written for American children annually.

The 2-day hearing to examine updated information about pediatric use of SSRIs was convened in the face of accusations that the FDA had been complicit in suppressing negative findings of clinical trials of the drugs after a series of leaked internal memos indicated it had gone to extraordinary lengths to stave-off a British-style prohibition.

Senior FDA epidemiologist Dr. Andrew D. Mosholder recommended a ban last December after reviewing 22 clinical trials involving 9 SSRIs. He found that 74 of 2298 adolescents taking antidepressants experienced a suicide-related event, as compared to 34 of 1952 children on placebos. He concluded that children on antidepressants were 1.89 times more likely to become suicidal.

But the FDA barred him from presenting his conclusions to a committee in February on the grounds that his analysis may have been skewed by misclassification of so-called "suiciderelated events," some of which may have been accidents.

The FDA opted to ask manufacturers to revise labels to urge closer monitoring of children, while commissioning researchers at Columbia University to re-examine the data.

According to an Aug. 16 memo written by Mosholder, this re-analysis indicated that children using the 9 antidepressants paroxetine (Paxil); sertraline
(Zoloft); venlafaxine (Effexor); fluoxetine (Prozac); citalopram (Celexa); mirtazapine (Remeron); nefazodone (Serzone), fluvoxamine (Luvox) and bupropion (Wellbutrin) — are 1.8 times more likely to become suicidal, with the rate varying from as low as 0.9 for fluoxetine to as high as 5.5 for fluvoxamine.

The re-analysis also concluded that the suicide risk estimates for the 2 most widely-used drugs, paroxetine and venlafaxine, among the 2298 adolescent users, was even higher than Mosholder had projected.

In suppressing Mosholder's conclusions, the FDA argued "inconsistencies" in clinical trial results made it difficult to know whether additional regulatory action was needed, with the apparent increased risk of suicidality needing to be balanced against the known risk of suicide when depression goes untreated.

The FDA advanced a similar argument earlier this month in

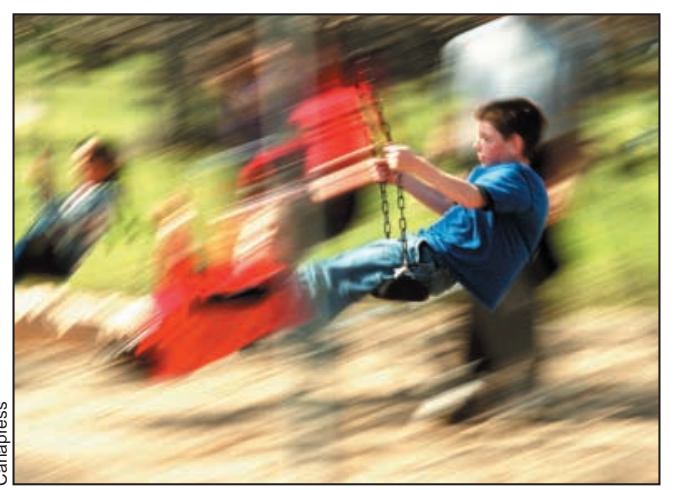

Up in the air: Should SSRIs be used for young patients? 
response to charges that its suppression of the negative research findings also included efforts to dissuade drug companies from including stronger warnings on their labels.

Pfizer vice-president Cathryn M. Clary told the US House Energy and Commerce subcommittee Sept. 9 that her firm was instructed by the FDA to not mention on sertraline labels that 2 studies had found the medication no more effective than placebo. In a letter to the firm filed with the subcommittee, the FDA said "we do not feel it would be useful to describe these negative trials in labelling, since these may be misinterpreted as evidence that Zoloft does not work."

FDA Deputy Commissioner for Operations Janet Woodcock also confirmed before the subcommittee that the agency had instructed Wyeth Pharmaceuticals that, rather than using the new warnings on labels for their drug venlafaxine, they should simply include a caution that physi- cians monitor the risk of suicide. Woodcock contended the FDA did not want to create the impression that the antidepressants were ineffective for children.

Concern that the FDA has been complicit in withholding information prompted Massachusetts congressman Edward J. Markey and California congressmen Henry A. Waxman to announce that they will introduce legislation requiring registry of all clinical trials and mandatory disclosure of all results.

"Drug companies can't be permitted to decide which trials to disclose and which to hide from the public. Doctors should never be put in the position of prescribing medications to a patient with only partial access to what is known about the drug's effects," Markey told CMA7.

The legislation is expected to be introduced in late September.

University of Toronto professor of pharmacy and medicine Dr. Jack Uetrecht says the controversy underscores the need to create results-based, rather than an intentions-based, clinical trial registries. "Companies should be forced to report all data, because there's a public need to know."

Others say the controversy points to a need for better postmarketing surveillance.

"There are many hazards, or potential hazards, that are not possible to detect on the relatively small-scale testing that is still done as the basis of formal toxicity tests," notes University of Toronto professor emeritus Dr. Harold Kalant.

"As drugs get more and more sophisticated, there are more chances of specific interactions with gene variants, or with other drugs, or with particular environmental factors. The only way you can assess is to see in post-marketing careful monitoring whether unanticipated, and perhaps un-anticipatable, adverse effects appear with some frequency and consistency of pattern." - Wayne Kondro, Ottawa

\section{ACCESS TO RESEARCH}

\section{New online medical journal challenges conventions}

A new scholarly journal joins the galaxy of medical publications this month, but unlike nearly all the others, it's Webbased and access is free.

PLoS Medicine (www.plos medicine.org/) goes online Oct. 19. Like its sister publication, PLoS Biology, which was launched a year ago, PLoS Medicine will be peer-reviewed.

Both ventures belong to the Public Library of Science (PLoS),

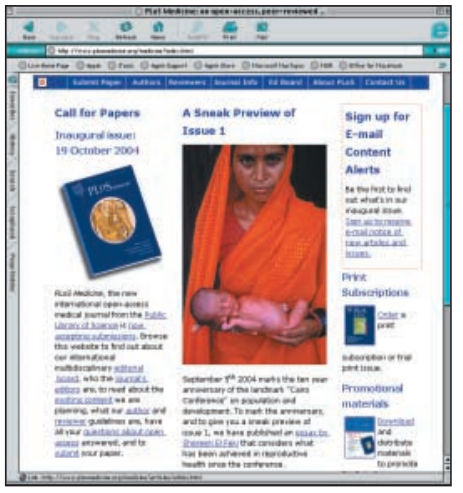

a non-profit, San Francisco-based coalition committed to making the world's scientific and medical literature a free public resource.

Instead of charging subscription fees to readers, PLoS charges the authors of accepted articles US\$1500 to help cover the cost of editing and publishing their work (CMA7 2003;169[7]: 700). The fee may be waived for researchers who can't afford it.

Whether this funding model is sustainable is something PLoS intends to discover. Observers at other journals insist that the upfront charge is too low to maintain a high calibre of editing and presentation. Barbara Cohen, senior editor for PLoS, says additional revenue could come from educational grants as well as carefully defined forms of advertising, nor does she rule out increasing the author fee.

"At the moment we think that this is a figure that is rea- sonable," she says. "We will have to learn over time whether it's realistic." Meanwhile, PloS has a US\$9-million start-up grant from the Gordon and Betty Moore Foundation.

Cohen says the online publication movement points to a need for systemic change, where science funders understand that the publication charge ... should become an integral part of doing the research."

That change is starting to take hold. Last month, the US National Institutes of Health proposed a new policy of insisting on free Internet access for papers based on work funded by the agency, regardless of whether that work appears in a paid subscription journal. The NIH argues that public funds paid for this work, and members of the public should not have to pay to read about it. - Tim Lougheed, Ottawa 